\title{
BRAND EXPERIENCE, PERCEIVED VALUE, BRAND TRUST UNTUK MEMPREDIKSI BRAND LOYALTY: BRAND LOVE SEBAGAI VARIABEL MEDIASI
}

\author{
Thomas Wilson Putra ${ }^{1}$, Keni $^{2}$ \\ ${ }^{1}$ Fakultas Ekonomi dan Bisnis, Universitas Tarumanagara \\ Email:Thomas.115160317@stu.untar.ac.id \\ ${ }^{2}$ Program Studi Magister Manajemen, Universitas Tarumanagara \\ Email:keni@fe.untar.ac.id
}

Masuk : 20-04-2020, revisi: 30-04-2020, diterima untuk diterbitkan : 30-04-2020

\begin{abstract}
ABSTRAK
Tujuan dari penelitian ini adalah untuk menguji apakah 1) pengalaman merek dapat memprediksi loyalitas merek. 2) persepsi nilai dapat memprediksi loyalitas merek. 3) kepercayaan merek dapat memprediksi loyalitas merek. 4) pengalaman merek dapat memprediksi kecintaan merek. 5) kecintaan merek dapat memprediksi loyalitas merek. 6) kecintaan merek memediasi prediksi pengalaman merek pada loyalitas merek. Data dikumpulkan dengan menggunakan kuesioner online. Totalnya, terkumpul sebanyak 220 responden. Hasil dari penelitian ini menunjukkan bahwa persepsi nilai dan kepercayaan merek merupakan prediktor positif dan signifikan terhadap loyalitas merek, sementara pengalaman merek merupakan prediktor negatif dan signifikan terhadap loyalitas merek. Pengalaman merek merupakan prediktor positif dan signifikan terhadap kecintaan merek. Kecintaan merek adalah prediktor positif dan signifikan terhadap loyalitas merek dan kecintaan merek merupakan mediator positif dan signifikan pengalaman merek terhadap loyalitas merek.
\end{abstract}

Kata Kunci: pengalaman merek, persepsi nilai, kepercayaan merek, kecintaan merek, loyalitas merek

\section{ABSTRACT}

The purpose of this research is to examine whether 1) brand experience can predict brand loyalty. 2) perceived value can predict brand loyalty. 3) brand trust can predict brand loyalty. 4) brand experience can predict brand love. 5) brand love can predict brand loyalty. 6) brand love mediates the prediction brand experience on brand loyalty. The data were collected using online questionnaire. In total 220 participants responded the survey. The result of this study indicate that perceived value and brand trust are positive and significant predictors towards brand loyalty, while brand experience is negative and significant predictors towards brand loyalty. Brand experience is a positive and significant predictor towards brand love. Brand love is a positive and significant predictor towards brand loyalty and brand love is positive and significant mediate brand experience towards brand loyalty.

Keywords: brand experience, perceived value, brand trust, brand love, brand loyalty

\section{PENDAHULUAN \\ Latar Belakang}

Perkembangan teknologi saat ini dapat berdampak pada berbagai aspek dalam kehidupan manusia. Dengan adanya kemajuan teknologi, kebutuhan dan keinginan masyarakat menjadi semakin mudah untuk terpenuhi. Kemudahan ini dapat menyebabkan pada perubahan perilaku dan kebiasaan seperti pola hidup yang ingin serba cepat atau instan. Permasalahan yang muncul antara lain yaitu tidak semua toko dan restoran memiliki media online untuk menerima pesanan kemudian melakukan pengiriman ke tempat tinggal para pelanggannya atau restoran yang diinginkan tidak bekerja sama dengan perusahaan ojek online. Salah satu alternatif yang paling banyak digunakan yaitu mengkonsumsi makanan instan. Makanan instan menjadi alternatif yang banyak digunakan karena dapat disimpan dalam jangka waktu yang cukup lama serta penyajiannya yang praktis dan cepat. Salah satu makanan instan yang paling digemari oleh masyarakat Indonesia adalah mi instan. Ketika sebuah produk dengan merek tertentu memiliki kualitas dan kredibilitas tinggi, merek itu cenderung menjadi prioritas utama pelanggan 
dibandingkan merek lainnya. Ketika pelanggan telah mencapai pada tingkat ini, maka komitmen tersebut akan mengarah pada meningkatnya loyalitas pelanggan terhadap suatu merek.

Brand loyalty dapat didefinisikan sebagai suatu komitmen kuat dan konsisten untuk membeli suatu barang dan jasa secara berulang-ulang (Oliver \& Rust, 1997). Loyalitas pelanggan terhadap sebuah merek sangat penting diukur, sehingga perusahaan-perusahaan dapat mengetahui perilaku pelanggan dan persepsi pelanggan terhadap merek yang bersangkutan. Brand loyalty dapat dikatakan memiliki andil terbesar dalam kesuksesan suatu perusahaan karena dapat memberikan segelintir manfaat seperti meningkatkan hasil penjualan dan pendapatan, mengurangi biaya akuisisi pelanggan, dan mengurangi tingkat kemungkinan beralihnya pelanggan loyal ke merek lain karena upaya pemasaran yang dilakukan oleh kompetitor (Rundle-Thiele \& Mackay, 2001).

Berdasarkan penelitian terdahulu, loyalitas pelanggan terhadap suatu merek juga dapat dirangsang oleh beberapa stimulus seperti penelitian yang dilakukan Huang (2017) yang mengatakan bahwa brand experience memiliki pengaruh tidak langsung terhadap brand loyalty, sedangkan brand love dan brand trust memiliki pengaruh langsung terhadap brand loyalty. Sementara menurut penelitian $\mathrm{Su}$ (2016) perceived value merupakan prediktor yang memberikan efek langsung terhadap brand loyalty. Lebih lanjut, Yang et al. (2017) dalam penelitiannya menemukan bahwa brand experience memiliki pengaruh yang signifikan terhadap brand loyalty.

Penelitian ini dilakukan dengan tujuan untuk melakukan pengujian secara empiris apakah brand experience, perceived value, brand trust, dan brand love dapat menjadi prediktor positif terhadap brand loyalty. Selain itu, penelitian ini juga dilakukan untuk menganalisis apakah brand love dapat menjadi mediator dalam hubungan antara brand experience dan brand loyalty. Diharapkan hasil dari penelitian ini dapat bermanfaat bagi perusahaan sebagai dasar dalam pengambilan keputusan dan perencanaan strategi serta dapat memberikan informasi yang relevan terkait dengan variabel-variabel yang dapat memberikan pengaruh yang signifikan terhadap brand loyalty.

\section{Telaah Kepustakaan \\ Brand loyalty}

Menurut Oliver (1999: 34) brand loyalty merupakan "a deeply held commitment to rebuy or repatronise a preferred product/service consistently in the future, thereby causing repetitive same-brand or same brand-set purchasing, despite situational influences and marketing efforts having the potential to cause switching behavior". Selain itu brand loyalty menurut Aaker (1991: 44) adalah: "... a measure of the attachment that a customer has to a brand." Berdasarkan pengertian brand loyalty di atas, dapat disimpulkan bahwa brand loyalty merupakan suatu prinsip atau komitmen yang dimiliki seorang pelanggan untuk melakukan pembelian atas produk yang sama secara berulang-ulang dalam jangka waktu yang cukup panjang sebagai bentuk keterikatan secara emosional dengan merek tertentu berdasarkan aspek penilaian pelanggan tersebut.

\section{Brand love}

Berdasarkan penelitian Carroll dan Ahuvia (2006: 81) brand love didefinisikan sebagai: "the degree of passionate emotional attachment a satisfied consumer has for a particular trade name”. Selain itu, Batra et al. (2012: 6) menjelaskan bahwa brand love adalah: “... a type of relationship (rather than as an emotion) that consumers establish with brands, encompassing multiple interrelated cognitive, affective, and behavioural elements, rather than a specific, single, transient love emotion". Dari uraian tersebut, dapat disimpulkan bahwa brand love merupakan sebuah hubungan keterikatan secara emosional antara pelanggan dengan sebuah 
merek yang terjadi sebagai bentuk respon dari kesesuaian kebutuhan yang dapat mengarah kepada loyalitas pelanggan terhadap suatu merek.

\section{Brand experience}

Menurut Brakus et al. (2009: 53) brand experience dapat didefinisikan sebagai: “... sensations, feelings, cognitions and behavioral responses evoked by brand-related stimuli that are part of a brand's design and identity, packaging, communications and environments". Sementara itu, dalam penelitian yang dilakukan Lasalle dan Britton (2002: 30) juga turut mengatakan bahwa brand experience merupakan: “... an interaction, or series of interactions, between a customer and a product, a company or its representative that lead to a reaction". Berdasarkan pengertian brand experience di atas, dapat disimpulkan bahwa brand experience merupakan suatu reaksi dan respon terhadap sebuah merek yang muncul sebagai bentuk hasil rangsangan dari interaksi pertama kali antara pelanggan dengan sebuah merek yang membuahkan persepsi tentang merek tersebut.

\section{Perceived value}

Dalam penelitian Netemeyer et al. (2004: 211) perceived value didefinisikan sebagai: “... the customer's overall assessment of the utility of the brand based on perceptions of what is received (e.g., quality, satisfaction) and what is given (e.g., price and nonmonetary costs) relative to other brands". Lebih lanjut, dalam buku Kotler dan Keller (2016: 151) mengatakan bahwa: "Customer-perceived value (CPV) is the difference between the prospective customer's evaluation of all the benefits and costs of an offering and the perceived alternatives". Berdasarkan pengertian perceived value di atas, dapat disimpulkan bahwa perceived value merupakan penilaian pelanggan atas evaluasi konsumsi berdasarkan seberapa besar manfaat yang akan diterima dibandingkan dengan seberapa besar upaya yang harus dikeluarkan untuk mendapatkannya.

\section{Brand trust}

Pada penelitian Chaudhuri dan Holbrook (2001: 82) menyatakan bahwa brand trust adalah: "the willingness of the average consumer to rely on the ability of the brand to perform its stated function". Selanjutnya penelitian Wang (2002: 62) menyatakan bahwa brand trust adalah: "the consumer's willingness to rely on a brand in which he or she had confidence with regard to the brand's reliability, honest, and altruism". Berdasarkan pengertian brand trust di atas, dapat disimpulkan bahwa brand trust merupakan suatu ikatan hubungan pelanggan dengan sebuah merek yang dilandaskan atas rasa aman dan kepercayaan bahwa merek tersebut dapat diandalkan dalam pemenuhan kepentingan dan kebutuhan pelanggan.

\section{Kaitan antara Brand experience dan Brand loyalty}

Pengalaman pelanggan yang memuaskan terhadap sebuah merek merupakan modal awal yang sangat baik dalam meningkatkan brand loyalty. Morrison dan Crane (2007) mengatakan bahwa menciptakan brand experience yang unik dan berkesan sangat penting untuk meningkatkan brand loyalty. Pelanggan akan mengkonsumsi produk dengan merek yang sama secara berulangulang ketika merasakan pengalaman yang unik dan berkesan, serta hal tersebut dapat mendorong meningkatnya loyalitas pelanggan terhadap merek tertentu (Brakus et al., 2009). Hubungan di antara dua variabel ini dapat diperkuat melalui hasil penelitian yang dilakukan oleh Khan et al. (2016a), Khan et al. (2016b) dan Yang et al. (2017) yang menyatakan bahwa pengalaman yang berkesan terkait suatu brand dapat memberikan efek langsung pada tingkat loyalitas pelanggan. Berdasarkan uraian di atas, hipotesis penelitian $\left(\mathrm{H}_{1 \mathrm{a}}\right)$ adalah:

$\mathrm{H}_{1 \mathrm{a}}$ : Brand experience dapat memprediksi secara positif terhadap brand loyalty. 


\section{Kaitan antara Perceived value dan Brand loyalty}

Perceived value berada pada level abstraksi tertinggi yang dimiliki sebuah merek dibandingkan dengan atribut dan manfaat apapun (Su \& Chang, 2018). Perceived value yang besar dapat memberikan dampak positif terhadap loyalitas pelanggan dengan sebuah merek. Ketika seorang pelanggan merasakan manfaat yang besar dari suatu merek, hal tersebut merupakan cara instan untuk mempertahankan brand loyalty (Hussain, 2016). Terdapat beberapa penelitian terdahulu yang melakukan pengujian terhadap hubungan kedua variabel ini, antara lain yang dilakukan oleh Su \& Chang (2018) yang mengatakan bahwa perceived value secara positif dan kuat mempengaruhi brand loyalty. Lebih lanjut $\mathrm{Su}$ (2016) mengatakan bahwa perceived value merupakan prediktor penting dalam menentukan loyalitas. Selain itu, hasil penelitian yang dilakukan oleh Hussain (2016) dan Su (2016) dapat membuktikan hubungan antara perceived value dengan brand loyalty. Berdasarkan uraian di atas, hipotesis penelitian $\left(\mathrm{H}_{1 \mathrm{~b}}\right)$ adalah:

$\mathrm{H}_{1 \mathrm{~b}}$ : Perceived value dapat memprediksi secara positif terhadap brand loyalty.

\section{Kaitan antara Brand trust dan Brand loyalty}

Kepercayaan pelanggan juga dapat memberikan dampak yang signifikan bagi kesuksesan suatu merek. Ketika suatu merek dapat konsisten dalam memenuhi kebutuhan dan harapan pelanggan, maka pelanggan cenderung akan mempercayai merek tersebut (Chinomona, 2016), sehingga dapat menjamin timbulnya brand loyalty dalam prosesnya (Chiou \& Droge, 2006). Dengan demikian, hasil penelitian Huang (2017), Chinomona (2016) serta Veloutsou (2015) dapat membuktikan tingginya kepercayaan pelanggan untuk suatu merek berdampak langsung pada meningkatnya loyalitas pelanggan terhadap merek tersebut. Selain itu, hubungan kedua variabel ini diperkuat dengan pernyataan Chinomona (2016) dalam penelitiannya yang mengatakan bahwa semakin tinggi tingkat kepercayaan pelanggan terhadap merek, semakin tinggi loyalitas pelanggan pada suatu merek yang diharapkan. Lebih lanjut Veloutsou (2015) mengatakan dalam penelitiannya bahwa kepercayaan telah diakui sebagai pengaruh penting dalam membentuk komitmen pelanggan yang mengarah pada loyalitas. Berdasarkan uraian di atas, hipotesis penelitian $\left(\mathrm{H}_{1 \mathrm{c}}\right)$ adalah:

$\mathrm{H}_{1 \mathrm{c}}$ : Brand trust dapat memprediksi secara positif terhadap brand loyalty.

\section{Kaitan antara Brand experience dan Brand love}

Brand experience merupakan topik mendasar dalam pemasaran yang melibatkan perasaan serta akan menghasilkan pengalaman yang tinggi dan lengkap (Portas, 2017). Dalam upaya untuk memenuhi kebutuhannya, pelanggan akan mencari produk dengan merek yang terdengar tidak asing di benaknya atau merek yang pernah dibeli sebelumnya. Ketika pelanggan memiliki brand experience yang positif, maka hal tersebut dapat mengarahkan pelanggan kepada brand love (Roy et al., 2013). Hasil penelitian yang dilakukan oleh Huang (2017), Sarkar et al. (2019) serta Portas (2017) memperkuat argumen bahwa terdapat hubungan yang signifikan dan positif antara brand experience dengan brand love. Berdasarkan uraian di atas, hipotesis penelitian $\left(\mathrm{H}_{2}\right)$ adalah:

$\mathrm{H}_{2}$ : Brand experience dapat memprediksi secara positif terhadap brand love.

\section{Kaitan antara Brand love dan Brand loyalty}

Apabila seorang pelanggan mulai menyukai sebuah merek, keinginan untuk mengkonsumsi dan loyal pada merek tersebut menjadi lebih besar, serta bersedia mengeluarkan upaya dan sumber daya yang lebih besar untuk mendapatkannya (Carroll \& Ahuvia, 2006; Batra et al., 2012). . Hasil penelitian yang dilakukan oleh Huang (2017), Bairrada et al. (2018), Song et al. (2019) dan Sarkar et al. (2019) dapat membuktikan adanya pengaruh positif brand love terhadap brand loyalty. Penelitian Bairrada et al. (2018) menyimpulkan bahwa brand love merupakan unsur 
penting bagi perusahaan dengan visi jangka panjang yang bertujuan untuk memperkuat hubungan antara pelanggan dengan sebuah merek. Berdasarkan uraian di atas, hipotesis penelitian $\left(\mathrm{H}_{3}\right)$ adalah:

$\mathrm{H}_{3}$ : Brand love dapat memprediksi secara positif terhadap brand loyalty.

\section{Kaitan antara Brand experience dan Brand loyalty yang dimediasi Brand love}

Pengalaman pelanggan dengan sebuah merek yang menyenangkan dan dapat memberikan kesan positif dapat secara langsung mempengaruhi rasa cinta pelanggan terhadap merek tersebut (Huang, 2017). Semakin baik pengalaman yang dirasakan pelanggan dengan suatu merek, semakin tinggi pula rasa cinta pelanggan pada merek tersebut. Oleh karena itu, pengalaman yang positif juga dapat menjadi rangsangan bagi pelanggan untuk menjadi loyal terhadap suatu merek. Brand loyalty dapat dicapai dengan dimulai dari hal yang penting seperti brand experience yang lalu diikuti oleh ranah emosional yaitu brand love (Keller, 2013). Hal ini dapat diperkuat dengan hasil penelitian yang dilakukan oleh Huang (2017) yang menyatakan bahwa brand love memiliki efek mediasi dalam hubungan antara brand experience dengan brand loyalty. Berdasarkan uraian di atas, hipotesis penelitian $\left(\mathrm{H}_{4}\right)$ adalah:

$\mathrm{H}_{4}$ : Brand love dapat memediasi prediksi secara positif brand experience terhadap brand loyalty.

Berdasarkan uraian kaitan antar variabel di atas, maka model penelitian yang digunakan dalam penelitian ini dapat digambarkan sebagai berikut:

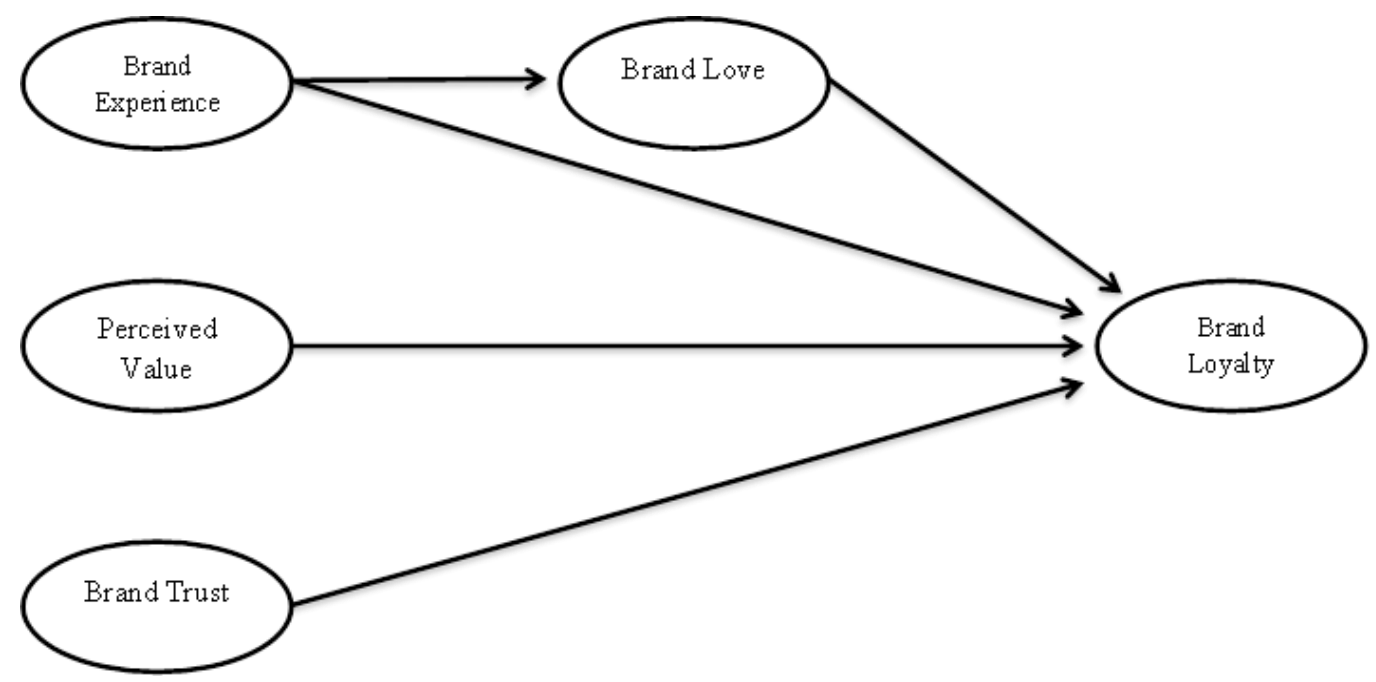

Gambar 1. Model penelitian

\section{METODE PENELITIAN}

Desain penelitian yang digunakan dalam penelitian ini yaitu deskriptif dengan menggunakan cross-section designs karena hanya dilakukan sekali dalam waktu tertentu. Sampel yang digunakan dalam penelitian ini adalah seluruh pelanggan mi instan yang dipilih dengan menggunakan teknik convenience sampling. Jumlah sampel yang berhasil dikumpulkan menggunakan kuesioner secara online melalui Google Forms sebanyak 220 responden. Berdasarkan 220 responden yang berhasil dikumpulkan diketahui mayoritas responden berjenis kelamin wanita (51,8\%), berusia 19-24 tahun (85\%), berpendidikan terakhir SMA/SMK/Sederajat (89.5\%), memiliki pekerjaan sebagai pelajar/Mahasiswa $(82,3 \%)$. 


\begin{tabular}{|c|c|c|}
\hline Variabel & Item & Sumber \\
\hline Brand loyalty & 5 item & Veloutsou (2015); Su (2016) \\
\hline Brand love & 6 item & $\begin{array}{l}\text { Carroll dan Ahuvia (2006); Song et al. (2019); Albert et al. (2009); } \\
\text { Ismail dan Spinelli (2012) }\end{array}$ \\
\hline Brand experience & 6 item & Kim et al. (2018); Brakus et al (2009) \\
\hline Perceived value & 5 item & Su (2016); Sweeney dan Soutar (2001) \\
\hline Brand trust & 5 item & Veloutsou (2015); Delgado-Ballester et al. (2003) \\
\hline
\end{tabular}

Variabel-variabel dalam penelitian ini diukur dengan menggunakan skala Likert 5 poin dengan angka 1 menunjukkan "Sangat Tidak Setuju" dan 5 menunjukkan "Sangat Setuju". Setelah dilakukan analisis validitas dan reliabilitas, hanya tersisa 21 item pengukuran dari total 27 item pengukuran bagi masing-masing variabel karena apabila nilai loading factor indikator suatu variabel <0,4 maka indikator tersebut dapat dihapuskan dari model penelitian (Henseler et al. 2009). Setelah dilakukan beberapa penyesuaian, 21 item pengukuran yang tersisa memiliki nilai AVE diatas 0,5, nilai Loading factor diatas 0,7 dimana hal tersebut telah memenuhi kriteria validitas konvergen, serta telah memenuhi kriteria validitas diskriminan Fornell-Larcker dan Cross Loadings. Lebih lanjut, hasil analisis reliabilitas menunjukkan bahwa semua variabel memiliki nilai Cronbach's Alpha dan Composite Reliability diatas 0,6 yang mengindikasikan variabel dalam penelitian tersebut reliabel (Maholtra, 2020).

\section{HASIL DAN PEMBAHASAN}

Pengujian path coefficient berfungsi untuk mengetahui arah dan apakah hubungan antara variabel independen dan variabel dependen pada model penelitian kuat atau lemah. Berikut hasil pengujian bootstraping akan disajikan dalam bentuk tabel.

Tabel 2. Hasil Analisis Path Coefficient

\begin{tabular}{ccccc} 
Hipotesis & Variabel & Path Coefficient & t-statistics & P-Values \\
\hline $\mathrm{H}_{1 \mathrm{a}}$ & Brand experience $»$ Brand loyalty & $-0,291$ & 3,718 & 0,000 \\
\hline $\mathrm{H}_{1 \mathrm{~b}}$ & Perceived value $»$ Brand loyalty & 0,291 & 2,920 & 0,002 \\
\hline $\mathrm{H}_{1 \mathrm{c}}$ & Brand trust $»$ Brand loyalty & 0,194 & 2,026 & 0,021 \\
\hline $\mathrm{H}_{2}$ & Brand experience $»$ Brand love & 0,677 & 16,705 & 0,000 \\
\hline $\mathrm{H}_{3}$ & Brand love $»$ Brand loyalty & 0,273 & 3,066 & 0,001 \\
\hline $\mathrm{H}_{4}$ & $\begin{array}{c}\text { Brand experience } » \text { Brand love } » \text { Brand } \\
\text { loyalty }\end{array}$ & 0,185 & 2,964 & 0,002
\end{tabular}

Berdasarkan hasil pengujian path coefficient yang disajikan dalam bentuk tabel di bawah, dapat disimpulkan bahwa brand experience dan perceived value merupakan variabel yang memiliki nilai koefisien terbesar dalam memprediksi brand loyalty dibandingkan variabel lainnya yaitu sebesar -0,291 dan 0,291. Setelah brand experience dan perceived value, variabel yang memiliki nilai koefisien terbesar dalam memprediksi brand loyalty yaitu brand love sebesar 0,273 diikuti dengan brand trust yang memiliki nilai koefisien sebesar 0,194. Selanjutnya, dari keempat variabel yang digunakan untuk memprediksi brand loyalty, semuanya memiliki hubungan yang positif kecuali brand experience.

Berdasarkan pada hasil pengujian hipotesis $\left(\mathrm{H}_{1 \mathrm{a}}\right)$, diketahui bahwa brand experience dapat memprediksi secara negatif brand loyalty, sehingga terbukti bahwa hipotesis $\left(\mathrm{H}_{1 \mathrm{a}}\right)$ ditolak. Hasil ini memiliki perbedaan dengan hasil penelitian yang dilakukan oleh Khan et al. (2016a), Khan et al. (2016b) dan Yang et al. (2017), dimana hasil dari ketiga penelitian ini menunjukkan bahwa brand experience dapat memprediksi brand loyalty secara positif. Iglesias et al. (2011) yang mengatakan bahwa brand experience yang baik dari pelanggan hanya akan mengarah kepada 
brand loyalty yang tinggi apabila nilai-nilai perilaku untuk memiliki komitmen antara pelanggan dan suatu merek sudah dikembangkan.

Selanjutnya hasil pengujian hipotesis $\left(\mathrm{H}_{1 \mathrm{~b}}\right)$, diketahui bahwa perceived value memprediksi secara positif brand loyalty, sehingga terbukti bahwa hipotesis $\left(\mathrm{H}_{1 \mathrm{~b}}\right)$ tidak ditolak. Hasil ini sejalan dengan penelitian yang dilakukan Su (2016), Hussain (2016) dan Su dan Chang (2018) dimana perceived value dapat memprediksi brand loyalty pelanggan. Hal ini selaras dengan yang dikatakan Su dan Chang (2018) bahwa ketika seorang pelanggan merasakan bahwa suatu merek memiliki nilai yang tinggi, pelanggan tersebut cenderung akan membeli merek yang sama terus menerus di masa yang akan datang.

Lebih lanjut, hasil pengujian hipotesis $\left(\mathrm{H}_{1 \mathrm{c}}\right)$ menunjukkan bahwa brand trust memprediksi brand loyalty, sehingga dapat disimpulkan bahwa hipotesis $\left(\mathrm{H}_{1 \mathrm{c}}\right)$ tidak ditolak. Hasil ini selaras dengan hasil penelitian yang dilakukan Huang (2017), Veloutsou (2015) dan Chinomona (2016) yang menemukan bahwa brand trust memiliki efek positif terhadap brand loyalty. Chiou dan Droge (2006) mengatakan bahwa merek yang dapat dipercaya oleh pelanggan adalah merek yang dapat menepati janjinya melalui kualitas produk yang unggul sehingga hal tersebut dapat menjamin loyalitas pelanggan terhadap merek tersebut dalam prosesnya.

Hasil pengujian terhadap $\left(\mathrm{H}_{2}\right)$ menunjukkan bahwa brand experience memprediksi secara positif brand love, maka dapat disimpulkan bahwa $\left(\mathrm{H}_{2}\right)$ tidak ditolak. Hasil ini diperkuat dengan hasil penelitian terdahulu oleh Huang (2017), Portas et al. (2017) dan Sarkar et al. (2019) yang menyimpulkan bahwa brand experience yang positif dapat meningkatkan brand love. Carrol dan Ahuvia (2006) menyatakan bahwa kebanyakan dari pelanggan yang merasa puas dengan pengalaman terhadap merek tertentu, akan mulai menyukai merek tersebut. Pelanggan cenderung menyukai sebuah merek ketika pelanggan merasa bahwa merek tersebut dapat diandalkan dan dapat bergantung pada merek tersebut sama seperti halnya seseorang dengan pasangannya (Sarkar et al., 2019).

Berdasarkan pada hasil pengujian $\left(\mathrm{H}_{3}\right)$, menunjukkan bahwa brand love dapat memprediksi secara positif brand loyalty, dengan demikian $\left(\mathrm{H}_{3}\right)$ dinyatakan tidak ditolak. Hasil ini diperkuat dengan hasil penelitian yang dilakukan oleh Huang (2017), Bairrada et al. (2018), Song et al. (2019) dan Sarkar et al. (2019) yang menyimpulkan bahwa brand love yang tinggi dapat meningkatkan brand loyalty. Seperti halnya yang dikatakan Roberts (2006), bahwa kesukaan atau kecintaan pelanggan terhadap suatu merek dapat berkontribusi kepada loyalitas terhadap merek yang kuat sebagai bentuk fundamental dari hubungan emosional antara merek dengan pelanggan.

Selanjutnya, hasil pengujian $\left(\mathrm{H}_{4}\right)$ menunjukkan bahwa brand love mampu memediasi prediksi secara positif hubungan brand experience dan brand loyalty, sehingga $\left(\mathrm{H}_{4}\right)$ tidak ditolak. Hasil ini didukung oleh penelitian yang dilakukan Huang (2017) yang menyimpulkan bahwa variabel brand love dapat menjadi mediator positif dalam hubungan brand experience dan brand loyalty. Rasa kesukaan pelanggan terhadap suatu merek dapat timbul melalui banyaknya pengalaman positif yang dirasakan ketika mengkonsumsi produk tersebut. Dengan begitu, pengalaman yang positif dapat menimbulkan rasa keterikatan secara emosional antara seorang pelanggan dengan merek tertentu yang pada gilirannya dapat menciptakan perilaku loyalitas terhadap merek tersebut pada waktu mendatang. 


\section{KESIMPULAN DAN SARAN}

Kesimpulan yang dapat diambil berdasarkan hasil penelitian ini adalah Perceived value dan Brand trust merupakan prediktor yang signifikan dan positif terhadap Brand loyalty, sedangkan Brand experience merupakan prediktor yang signifikan namun negatif terhadap Brand loyalty. Selain itu, hasil penelitian ini juga menemukan bahwa Brand experience dapat menjadi prediktor yang signifikan dan positif terhadap Brand love, serta Brand love dapat menjadi prediktor yang signifikan dan positif bagi Brand loyalty. Lebih lanjut, Brand love dapat menjadi mediator dalam hubungan antara Brand experience dan Brand loyalty.

Peneliti menyarankan agar perusahaan diharapkan dapat terus meningkatkan kreativitas menciptakan varian rasa dari produknya sehingga dapat memenuhi ekspektasi selera pelanggan sesuai dengan trend yang sedang terjadi saat ini. Hal ini perlu diperhatikan oleh perusahaan untuk mengurangi adanya kejenuhan pelanggan terhadap varian rasa yang tidak bervariasi dan mengikuti trend yang sedang booming saat ini. Selain itu, perusahaan harus tetap memperhatikan value dari produknya dengan cara menjaga cita rasa produk mulai dari bahan-bahan pokok serta pendistribusian yang baik, sehingga dapat memberikan produk yang memiliki nilai tinggi dari segi manfaat, harga yang terjangkau, dan mudah untuk ditemui oleh pelanggan.

Untuk penelitian selanjutnya, peneliti menyarankan untuk menambah jumlah sampel dan memperluas cakupan populasi yang digunakan sehingga penelitian dapat memberikan hasil yang lebih akurat dalam mengukur loyalitas pelanggan serta tidak lupa untuk memperluas variabelvariabel yang digunakan dalam memprediksi loyalitas pelanggan, sehingga variabel yang digunakan dalam penelitian selanjutnya dapat memprediksi secara lebih akurat dan terukur serta memiliki kontribusi yang lebih besar dalam memprediksi loyalitas pelangan.

\section{Ucapan Terima Kasih}

Peneliti mengucapkan banyak terima kasih kepada pihak-pihak yang turut membantu dalam pengumpulan data serta memberikan dukungan, saran dan motivasi selama proses penelitian ini dilakukan dari awal hingga selesai.

\section{REFERENSI}

Aaker, D.A. (1991). Managing Brand Equity: Capitalizing on the Value of a Brand Name, The Free Press, New York, NY.

Ahuvia, A. C., Batra, R., \& Bagozzi, R. P. (2009). Love, desire and identity: A conditional integration theory of the love of things. The Handbook of Brand Relationships. New York: ..., June http://scholar.google.com/scholar?hl=en\&btnG=Search\&q=intitle:Love,+DesDes,+and+Id entity:+A+Conditional+Integration+Theory+of+the+Love+of+TThing\#0

Albert, N., Merunka, D., \& Valette-Florence, P. (2009). The feeling of love toward a brand: Concept and measurement. Advances in Consumer Research, 36(May 2014), 300-307.

Bairrada, C. M., Coelho, F., \& Coelho, A. (2018). Antecedents and outcomes of brand love: utilitarian and symbolic brand qualities. European Journal of Marketing, 52(3-4), 656682. https://doi.org/10.1108/EJM-02-2016-0081

Barajas-Portas, K. (2017). Analysing Brand Love: Integration of Predictive Validity for PLS Models. International Journal of Marketing \& Business Communication, 6(4), 1-8. http://proxy2.hec.ca/login?url=https://search.proquest.com/docview/2024035816?accounti $\mathrm{d}=11357 \% 0 \mathrm{Ahttp} / / / \mathrm{kk} 9 \mathrm{fd} 4 \mathrm{ag} 5 \mathrm{~g}$.search.serialssolutions.com?ctx_ver=Z39.88-

2004\&ctx_enc=info:ofi/enc:UTF-

8\&rfr_id=info:sid/ProQ\%3Aabiglobal\&rft_val_fmt=info:ofi/fmt:kev:mtx: 
Batra, R., Ahuvia, A., \& Bagozzi, R. P. (2012). Brand love. Journal of Marketing, 76(2), 1-16. https://doi.org/10.1509/jm.09.0339

Brakus, J. J., Schmitt, B. H., \& Zarantonello, L. (2009). Brand Experience: What Is It? How Is It Measured? Does It Affect Loyalty? Journal of Marketing, 73(3), 52-68. https://doi.org/10.1509/jmkg.73.3.52

Carroll, B. A., \& Ahuvia, A. C. (2006). Some antecedents and outcomes of brand love. Marketing Letters, 17(2), 79-89. https://doi.org/10.1007/s11002-006-4219-2

Chaudhuri, A. and Holbrook, B.M. (2001). The chain of effects from brand trust and brand affects to brand performance: the role of brand loyalty. Journal of Marketing, 65(2), 81-93.

Chinomona, R. (2016). Brand communication, brand image and brand trust as antecedents of brand loyalty in Gauteng Province of South Africa. African Journal of Economic and Management Studies, 7(1), 124-139. https://doi.org/10.1108/AJEMS-03-2013-0031

Chiou, J. S., \& Droge, C. (2006). Service quality, trust, specific asset investment, and expertise: Direct and indirect effects in a satisfaction-loyalty framework. Journal of the Academy of Marketing Science, 34(4), 613-627. https://doi.org/10.1177/0092070306286934

Garson, G. D. (2016). Partial Least Squares: Regression \& Structural Equation Models. In G. David Garson and Statistical Associates Publishing.

Hair, J. F., Ringle, C. M., \& Sarstedt, M. (2011). PLS-SEM: Indeed a silver bullet. Journal of Marketing Theory and Practice, 19(2), 139-152. https://doi.org/10.2753/MTP10696679190202

Hair, J. F., Sarstedt, M., Hopkins, L., \& Kuppelwieser, V. G. (2014). Partial least squares structural equation modeling (PLS-SEM): An emerging tool in business research. European Business Review, 26(2), 106-121. https://doi.org/10.1108/EBR-10-2013-0128

Henseler, J., Ringle, C. M., \& Sinkovics, R. R. (2009). The use of partial least squares path modeling in international marketing. Advances in International Marketing, 20(2009), 277319. https://doi.org/10.1108/S1474-7979(2009)0000020014

Huang, C. C. (2017). The impacts of brand experiences on brand loyalty: mediators of brand love and trust. Management Decision, 55(5), 915-934. https://doi.org/10.1108/MD-102015-0465

Hussain, R. (2016). The mediating role of customer satisfaction: evidence from the airline industry. Asia Pacific Journal of Marketing and Logistics, 28(2), 234-255. https://doi.org/10.1108/APJML-01-2015-0001

Khan, I., Rahman, Z., \& Fatma, M. (2016). The role of customer brand engagement and brand experience in online banking. International Journal of Bank Marketing, 34(7), 1025-1041. https://doi.org/10.1108/IJBM-07-2015-0110

Khan, I., Rahman, Z., \& Fatma, M. (2016). The concept of online corporate brand experience: an empirical assessment. Marketing Intelligence and Planning, 34(5), 711-730. https://doi.org/10.1108/MIP-01-2016-0007

Kim, M. S., Shin, D. J., \& Koo, D. W. (2018). The influence of perceived service fairness on brand trust, brand experience and brand citizenship behavior. International Journal of Contemporary Hospitality Management, 30(7), 2603-2621. https://doi.org/10.1108/IJCHM-06-2017-0355

Kotler, Philip \& Kevin Lane Keller, (2016): Marketing Management, 15th Edition New Jersey: Pearson Pretice Hall, Inc.

Lasalle, D. and T. A. Britton (2002). Priceless: Turning Ordinary Products into Extraordinary Experiences. Boston: Harvard Business School Press.

Malhotra, N. K. (2020) Marketing Research: An Applied Orientation. Essex: Pearson 
Morrison, S., \& Crane, F. G. (2007). Building the service brand by creating and managing an emotional brand experience. Journal of Brand Management, 14(5), 410-421. https://doi.org/10.1057/palgrave.bm.2550080

Munuera-Aleman, J. L., Delgado-Ballester, E., \& Yague-Guillen, M. J. (2003). Development and Validation of a Brand Trust Scale. International Journal of Market Research, 45(1), 1-18. https://doi.org/10.1177/147078530304500103

Netemeyer, R. G., Krishnan, B., Pullig, C., Wang, G., Yagci, M., Dean, D., Ricks, J., \& Wirth, F. (2004). Developing and validating measures of facets of customer-based brand equity. Journal of Business Research, 57(2), 209-224. https://doi.org/10.1016/S01482963(01)00303-4

Oliver, R.L. and Rust, R.T. (1997). Customer delight: foundations, findings, and managerial insight. Journal of Retailing, 73(3), 311-336.

Oliver, R. L. (1999). Whence consumer loyalty. Journal of Marketing, 63(4), 33-34.

Roberts, K. (2006), The Lovemarks Effect: Winning in the consumer revolution. New York: Powerhouse Books.

Roy, S. K., Eshghi, A., \& Sarkar, A. (2013). Antecedents and consequences of brand love. Journal of Brand Management, 20(4), 325-332. https://doi.org/10.1057/bm.2012.24

Rundle-Thiele, S. and Mackay, M.M. (2001). Assessing the performance of brand loyalty Measures. Journal of Services Marketing, 15(7), 529-546.

Sarkar, A., Sarkar, J. G., \& Bhatt, G. (2019). Store love in single brand retailing: the roles of relevant moderators. Marketing Intelligence and Planning, 37(2), 168-181. https://doi.org/10.1108/MIP-05-2018-0148

Song, H. J., Bae, S. Y., \& Han, H. (2019). Emotional comprehension of a name-brand coffee shop: focus on lovemarks theory. International Journal of Contemporary Hospitality Management, 31(3), 1046-1065. https://doi.org/10.1108/IJCHM-07-2017-0436

$\mathrm{Su}$, J. (2016). Examining the relationships among the brand equity dimensions: Empirical evidence from fast fashion. Asia Pacific Journal of Marketing and Logistics, 28(3), 464480. https://doi.org/10.1108/APJML-01-2015-0004

Su, J., \& Chang, A. (2018). Factors affecting college students' brand loyalty toward fast fashion: A consumer-based brand equity approach. International Journal of Retail and Distribution Management, 46(1), 90-107. https://doi.org/10.1108/IJRDM-01-2016-0015

Sweeney, J. C., \& Soutar, G. N. (2001). Consumer perceived value: The development of a multiple item scale. Journal of Retailing, 77(2), 203-220. https://doi.org/10.1016/S00224359(01)00041-0

Veloutsou, C. (2015). Brand evaluation, satisfaction and trust as predictors of brand loyalty: the mediator-moderator effect of brand relationships. Journal of Consumer Marketing, 32(6), 405-421. https://doi.org/10.1108/JCM-02-2014-0878

Yang, J., Zheng, R., Zhao, L., \& Gupta, S. (2017). Enhancing customer brand experience and loyalty through enterprise microblogs: Empirical evidence from a communication framework perspective. Information Technology and People, 30(3), 580-601. https://doi.org/10.1108/ITP-09-2015-0219 